\title{
Role Of Rural Women In Development And Export Earnings Of Pakistan's Dairy Industry
}

\author{
Saman Hussain \\ Department of Commerce \\ University of Karachi \\ Rummana Zaheer \\ Department of Economics \\ University of Karachi
}

\begin{abstract}
Dairy industry of Pakistan encounters many improving measurements to ensure the acceptability of its products in international market. For the purpose Pakistan Dairy Development Council (PDDC) introduces many innovative measures. While discussing the implication of these measures the training and skills of labor force working in industry matters a lot. It is the feature of Pakistan's dairy industry that a prominent ratio of its labor force is from the always neglected strata of society, the rural women. Women play both the direct and indirect role in managing livestock in rural regions of Pakistan. While observing role of dairy industry in export earnings, the services of its major labor force (rural women) should not be neglected. This paper is an attempt to discuss the development and export earnings of Pakistan's dairy industry and correspondence potential role of rural women with special reference to food security and poverty eradication in country. It is the descriptive analysis of data from 1961 to 2018 .
\end{abstract}

Keywords: Dairy Industry, Rural Women, Financial Assistance, Technical Education, Food Security, Poverty Eradication, Export Earnings.

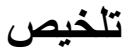

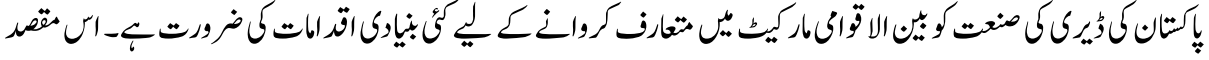

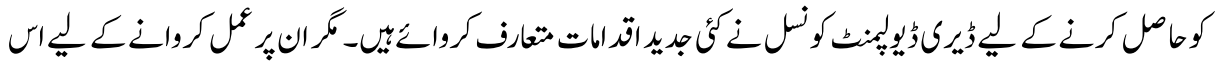

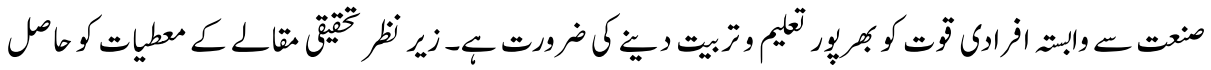

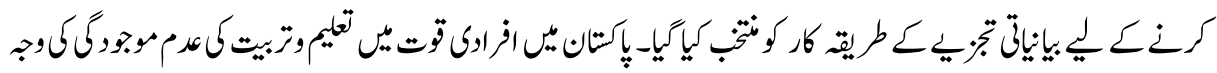

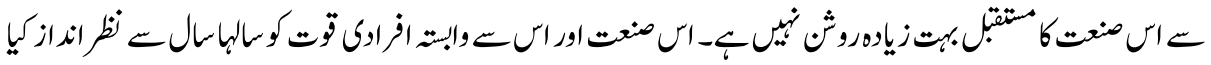

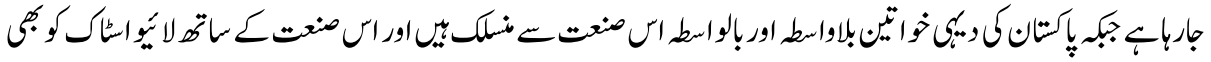

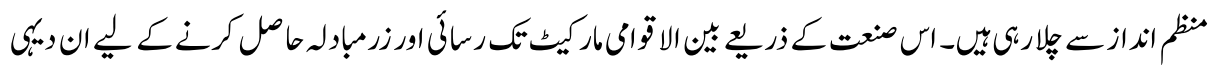

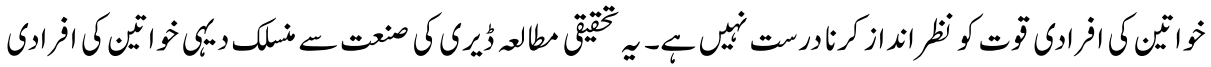




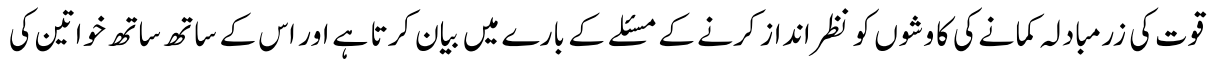

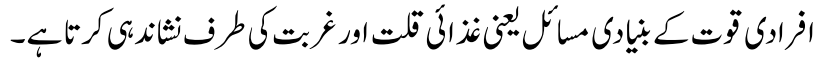

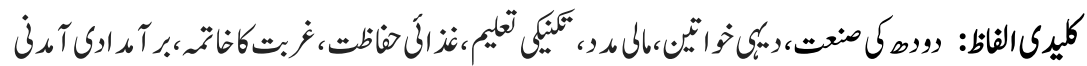

\section{Introduction}

Dairy industry is one among the potential export earning industries of Pakistan. The sector is based on livestock -the sub sector of agriculture with prominent employment and leading growth rate in gross domestic production (Economic Survey of Pakistan, 2016, 2017). In order to cope up the potential competitiveness of industry, some measures are seriously needed to get implication for better quality standard of dairy product. Among these, the training and skills of labor force working in industry matters a lot. It is the feature of Pakistan's dairy industry that a prominent ratio of its labor force is from the always neglected strata of society, the rural women. Women play both the direct and indirect role in managing livestock in rural regions of Pakistan.

While addressing the role of rural women in development of dairy industry, first there must be enlightened the significance of sector in the economic development of country. In this respect, facts and figures of socio-economic indicators in country stated livestock with a largest contribution to agriculture (as subsector) output for $60 \%$. This higher ratio of livestock production to agriculture is for the reason of its contribution of $11.61 \%$ to national GDP. And this is once again the higher contribution as compared to remaining subsectors (Economic Survey of Pakistan, 2017). Along this, Pakistan is also registered with the largest dairy production among top three countries of Asia and further to Pacific region as well. Moreover, the dairy report of 2017 conducted by International Farms Comparison Network (IFCN) stated Pakistan as the 3rd largest milk producing country in the world too. This highly competitive industry faces difficulties to participate in international market due to lack of quality standards. While addressing the improvements and revolutionary measures to exploit the potential of industry at international level, the factors of production involved in the industry needs serious attention. And among these the labor force in industry really needed to be analyzed for its efficiency. In this regard, we see the rural women as major participant in livestock management of rural areas of country. In rural areas of Pakistan, even in the era of globalization and information technology, women there are far behind to get registered themselves in commercial activities. In country's rural areas, poverty and food insecurity remains the hindering factors to development. While majority of the population living there are employing in agricultural sector with livestock farming. As like other developing countries in Pakistan there are a very large number of small farm holders whose participation is needed to be 
highlight. And interestingly these small farms are normally managed by women working there. The participation of rural women in livestock keeping activities is very prominent and considered as necessity in poor strata. The role of rural women in industry is always neglected despite of its significance in reduction of poverty and food insecurity in rural regions. Basically, this paper is an attempt to have a descriptive discussion on the role of rural women in the development of dairy sector of Pakistan along specifically addressing the food security and poverty eradication in country.

The present study is aimed to test via descriptive discussion for the following research hypothesis:

"The potential of dairy industry could be raise by promoting rural women in Pakistan."

The above research hypothesis also allowed the study to go through the answer of following research question.

"Is there any connectivity between poverty eradication, employment of rural women and productivity of dairy industry in Pakistan?"

This study is aimed to explore the following objectives through a descriptive framework:

- To review the significance of dairy industry of Pakistan,

- To highlight the role of rural women as labor force in dairy industry of Pakistan, and

- To discuss the potential export earnings of dairy sector of Pakistan.

\section{Review of Literature}

Agriculture sector is considered as the backbone of developing economy and dairy industry in this sector as subsector to economy plays a direct and crucial role in solution of two main problems first the food security and second eradication of poverty. According to Butt et al. (2010), dairy industry operates in supply of the raw material, intermediary and final products. Moreover, Gillispie, S. Harris, J. \& Kadiyala, S. (2012) suggests farm activities as a solution to the food security and poverty eradication in developing countries. For a successful take-off of an economy, Zaheer \& Hussain (a), (2015) also suggest development of dairy sector amongst the primary condition thus revolutionary reforms in this subsector are always remains in priority list. In development of dairy industry there lies two folds of benefit. Firstly, it contributes to Gross Domestic Production with food security and secondly it helps to eradicate poverty by allowing easier employment than any other sector. Behind stating it's development as primary condition is the fact of its complementary effects to other industries. While addressing the productivity and competitiveness of sector the major 
employing figure the rural women must be addressed. As their role in industry directly relates to efficiency of industry. Actually, rural women while getting busy with agricultural activities are normally seen to also be involved with livestock. Lal, R. \& Khurana, A. (2011) and Balgamwla et al. (2015) (a) while discussing role of rural women in dairy industry stated that it become easier for them to have livestock with cost cutting strategy while engaged in agricultural activities as this helps them to have an ultimate source of hygienic diet for family. Hence their participation in dairy industry is raised due to their commercial and non commercial activities as well. Women in rural areas also found being involved in the sector for non commercial purposes. Balgamwla et al. (2015) (b) highlighted a very common practice in rural region that in order to fulfill the dietary requirements of family, one or two animals are kept at home. Hussain \& Zaheer (2016) indicated that in rural areas dairy animals are managed by women and a minor step towards commercial activities is their practices of selling abundant dairy products than domestic need. These products are milk, lassi, ghee and butter. Normally the earnings from such activities are kept by women. Thus any improvement in the capability of rural women leads to betterment of industry's output as well as economic development.

The background of any industry includes the efficiency of factors of production especially the performance of labor. This plays an important role while being classified as unskilled, semi skilled and skilled. Zaheer \& Hussain (2018), while discussing the role of technical education in economic growth of Pakistan, stated that degree of skilfulness of labor is crucially important attribute of population of a country. In fact degree of skilfulness of a population is counted as human capital now a days. In literature its significance related investment activities is emphasized greatly. Likewise, Barro (1996) and Benhabib \& Spiegel (1994) evident the endowment of physical capital as significantly influencing to the larger human capital. The term of capital is widen with a larger magnitude of concept while enfolding the human capital. According to Mulligan \& Martin (1992) the higher the improvement will be in human capital of an economy the greater will be the increasing production there. Moreover, the dynamic agglomeration of human capital with education or knowledge became familiar since mid of 1960s. Related to this Rebelo (1987), Lucas (1988), Caballe \& Santos (1993) and Barro \&Martin (1995) used attributes of experience and education for measuring the human capital. As Romer (1986) stated that the socio-economic returns of a country also subject to the education promoting policies in a country. While emphasizing the role of education in economic activities, Nelson \& Phelps (1996) discussed the training programs to utilize technological advancements as necessary to get a faster level of absorption. Even the capability to avail financial aid is also subject 
to education. Financial assistance if on one side is dependent upon the policies of financial and other lending institutions then on the other end it also depends upon the competitiveness of borrower to get understanding of procedures and organize the disbursement in effective manner. This competitiveness can be improved by making an easier access to education to manpower in dairy industry. Zaheer \& Hussain (2018) while addressing factors affecting the production of dairy sector indicated the level of education as significantly positive influencing. The more the primary enrollment of population in rural areas the greater the improvement of production in dairy sector is observed by authors.

The key factor in export earnings of a sector depends upon the quality standards of production. If dairy sector lacks in quality standards, it transfers the deteriorating effects on economy. Thus, Dries, L. \& Noev, N. (2006) stated that for the promotion of industry at national and international level, it is recommended to facilitate the employing manpower in both technical and financial ends that can help in the enhancement of quality standards and management of farm activities respectively. Now while emphasizing the technical and financial assistance of education is needed to be on priority list. It means for this purpose the targeted strata must be highlighted. For instance Lal R. \& Khurana A. (2011) stated in the support of other studies that livestock keeping areas are rural areas in developing countries and the major employing strata in farm related activities are found women there. Rural women involved in farm related activities in the form of paid, unpaid family workers and self employed. While among these, Zaheer \& Hussain (2019) pointed out the unpaid family worker as higher in ratio to other forms. In small farms women are seen practicing as unpaid family workers and their contribution cannot get registered in developing countries. Kathiriya et al. (2013) observed that in large scale farms women are seen as paid workers and despite of their potential abilities in managing and keeping livestock are not observed as farm owner. Behind this, Rathor et al. (2016) argued their lackness in technical skills as very crucial. Gillispie et al. (2011) while discussing the role of rural women in dairy industry in India, observed that catering technical workshops on preserving and producing of different variety of dairy products helps women to raise their income level. This simply shows the significance of sector in poverty eradication. Moreover Gasson, (1980) also indicate the financial hurdle for keeping a larger herd that limitate their involvement in large scale farm activities. Author also highlighted the dairy farming of England as it is found to be very influencing for the financial assistance to women. Whereas, Dries \& Swinnen (2004) while discussing the effects of financial aid emphasized the need of prompt disbursement of dairy loans as it enables the farmer to get latest farm assistance and upgrading the investment at farm level as well. Lofstrom, M. (2009) 
and Zahir et al. (2011) while targeting dairy industry advocate the providence of technical and financial assistance to rural women, stating that it could be very fruitful to have an up gradation of productivity than before. As self employing will promote the commercial aptitude among them than working as low skilled labor. Begum, R. \& Yasmeen, G. (2011) and Balgamwla et al. (2015) (b) also emphasized the revolutionary steps for enabling the women labor force in dairy sector as this not only helps them to promote their social status but also contribute towards the development of industry and if, see with a broader view, development of economy as well.

\section{Research Methodology}

The present study is of archival nature that analyze the existing studies describing the role of rural women in development of dairy industry in country. For the purpose an overview of dairy industry to show its significance in economy along the performance of rural women in the development of sector has been discussed. The research framework has been structured as shown in Figure 6.1.

For addressing the first objective, this study reviews the significance of dairy industry in country, for this literature is also evident for proving industry's importance in socioeconomic development of a developing country and further this significance is discussed with reference to Pakistan. In order to address the second objective, role of rural women is discussed in literature highlighting the involvement in industry later on also highlights with respect to Pakistan. In this respect, the descriptive statistics and unit root analysis has also been done by examining the annual data from 1961 to 2018 . The final objective of the study is to explore the potential export earnings of industry that is done via describing its participation trend in international market.

\section{Research Framework}

The figure 6.1 is a proposed research frame work describing the flow to sustainable economic development of Pakistan via facilitating the rural women with specification in dairy industry. Rural women are found to be more involved in small scale farm activities hence if get facilitation in technical and financial ends will helps to promote the productivity of dairy sector that ultimately ensures the food security and poverty eradication in country and export earnings from international trade. Thus these all elements actually fuels to sustainable socio-economic development of Pakistan. 
Figure: 6.1

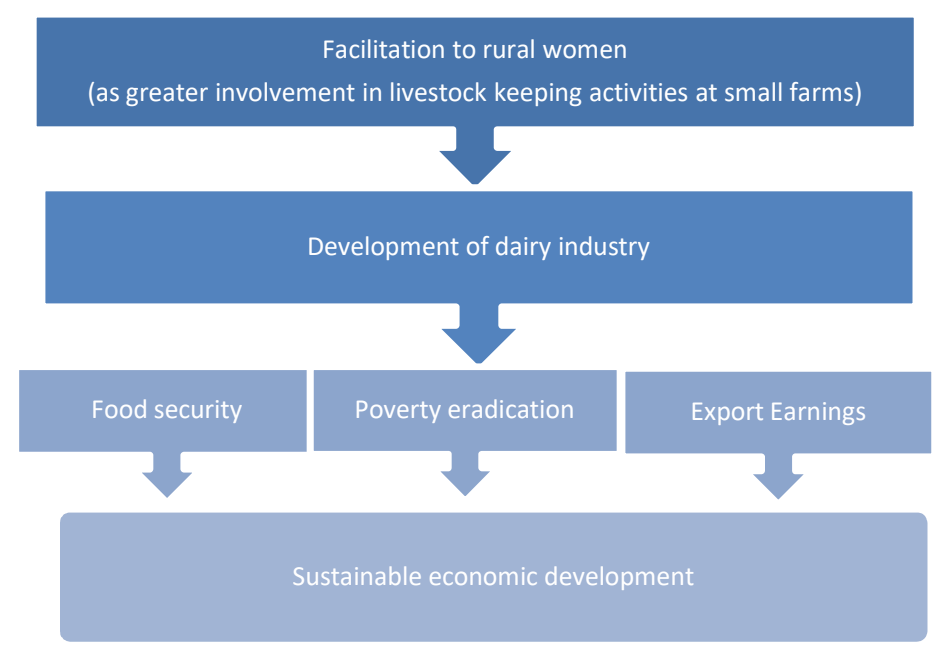

Source: Researchers' desk.

\section{The Dairy Industry of Pakistan}

There are about 8 million families employing with livestock sector whereas the ratio of their earnings are accounted for more than $35 \%$ attributed from the sector's activities. It is also observed that the period showing a negative output in agriculture sector was with the positive growth rate of livestock. The subsector of livestock has recorded positive growth rate on average for about 3\% annually to Agriculture (see table: 2 ).

The herds of cow and buffalo contributed $96 \%$ to overall milk production of sector. Whereas milk obtained from sheep, goat and camel got consumed by household rather selling it on commercial basis or sometimes it got mixed in the milk obtained from cow and buffalo. Now a day's milk of camel got popularity and seen as being sold marked its origination but this ratio is very smaller in overall commercial activities of the sector. While asses, mules, horses and camels are generally kept for transportation and sometimes traction as well. Along this usage bones, hair, hides, skins and wool are also obtained as byproduct of the sector. Moreover, livestock also used for drought purpose in rural areas of country. Almost every part of country contribute its share in over all milk production but the major ratio of milk supply is contributed by two provinces; Punjab and Sind.

The dairy sector prominently raise the milk production in order to reduce the demand and supply gap. Moreover, this increasing supply and demand gap of dairy products has also been affected due to militancy and periodic flooding in country (Ahmed et al. 2012). Figure. represents the milk supply in Pakistan and Figure shows the annual percentage 
changes in domestic supply. It is clearly evident that milk supply in country has increased prominently.

Figure 7.1 Milk supply in Pakistan

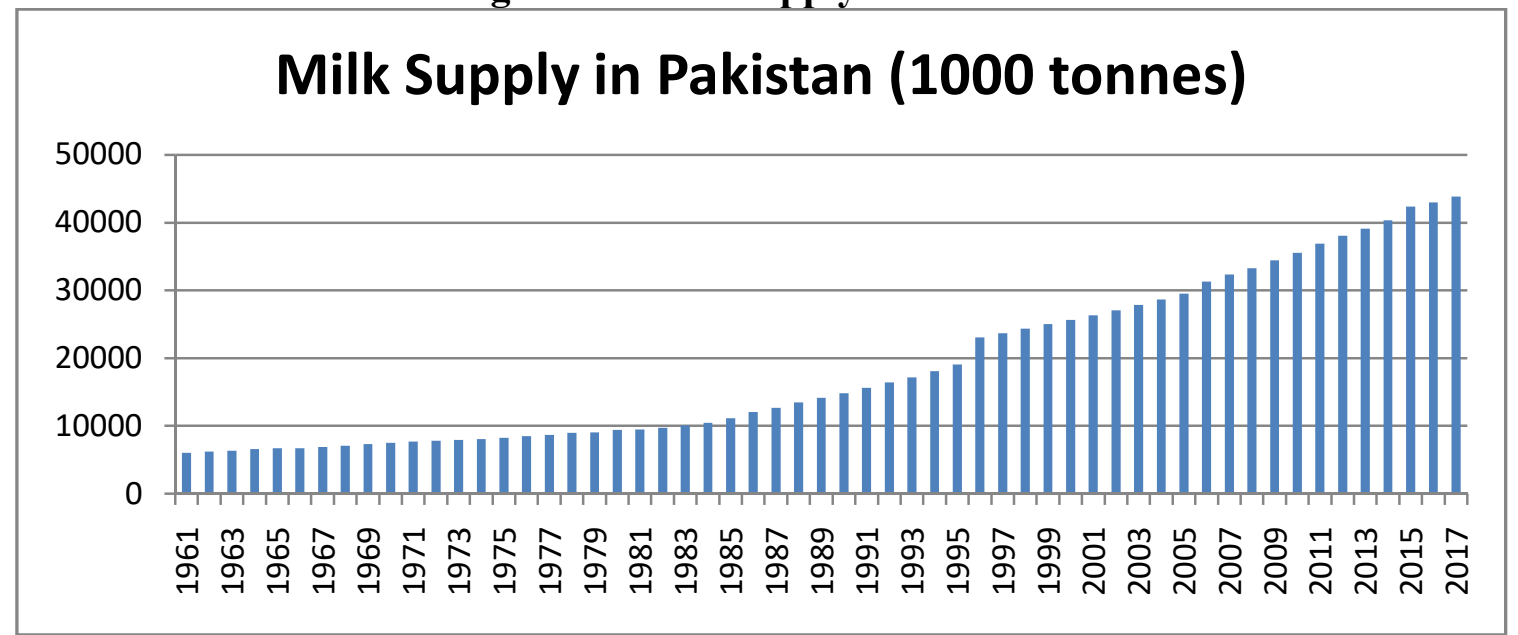

Source: Various reports of Bureau of Statistics of Pakistan.

Figure 7.2 Annual percentage change in domestic supply of milk

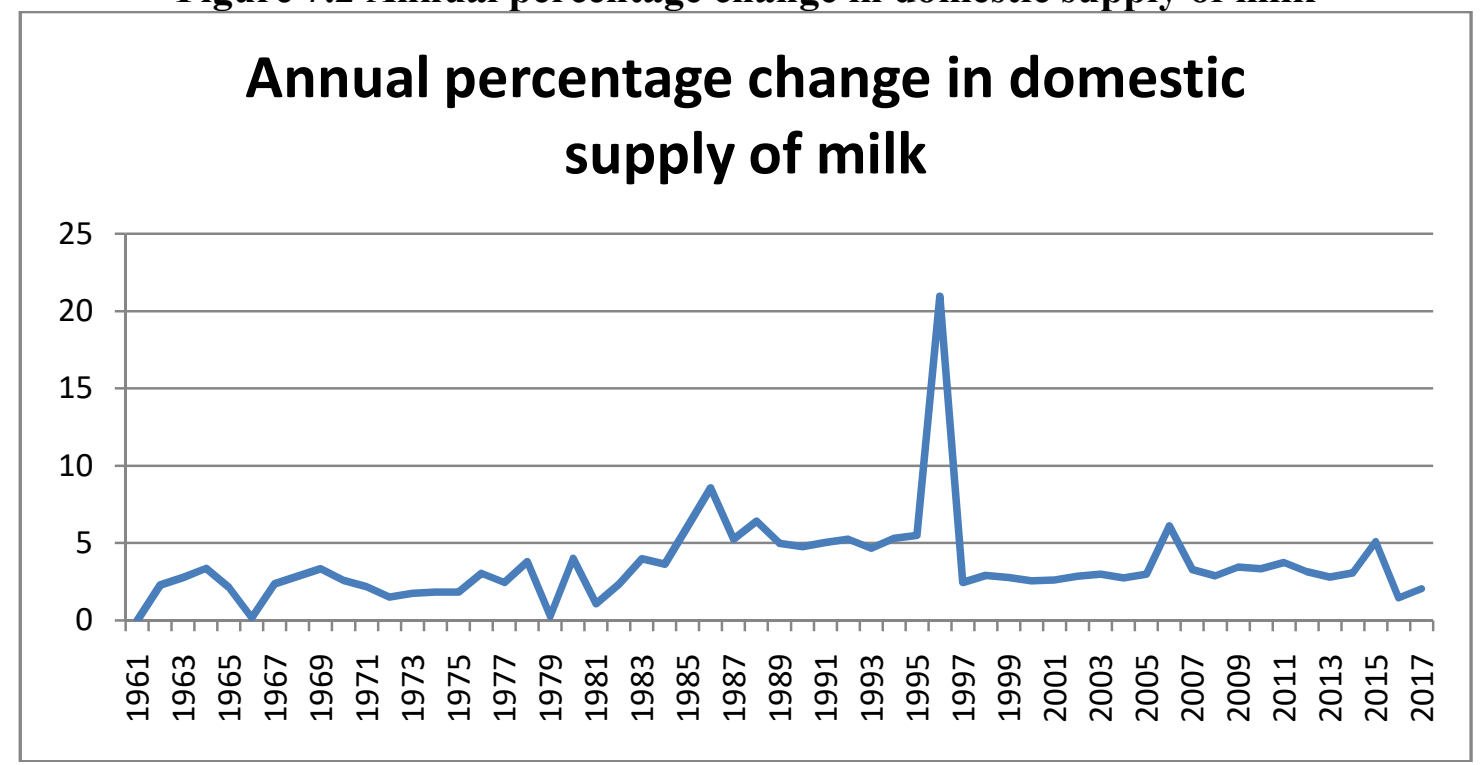

Source: Researchers' desk.

\section{Role of Rural Women in Sector}

The role of rural women in Pakistan's agriculture sector has always been ignored by both the rural sociologists and agricultural economists. The labor force in sector always 
considered as man by agricultural economists against the fact that more than the quarter of employed labor force in rural farms are women as both the paid and unpaid family workers. Agricultural economists and rural sociologists both considers the farm activities as employing by families in rural regions, and only lighten the role of rural women as a member of family. Whereas, women studies are only focusing the role of urban working women and housewives. But despite these all ignorance by academics, this strata's effort are self evident for producing and managing labor force along assistance in farm activities and commercial management and supporting the community there.

The rural region of Pakistan includes the involvement of both the genders; male and female in organizational and operational dairy farm activities. Related to this, a study done by Zaheer \& Hussain (2016) stated that rural women are generally spending over 15 hours per day in livestock keeping activities. These activities includes business management and farm production.

Rural women involved in agricultural activities are also found to be employed with livestock. As livestock is considered as complementary activity along other agricultural activities because of some reasons. The bushes and herbs that are removed from fields are used as feed of cattle and hens are rushed in fields to get insects and other feed. It reduces the livestock keeping cost.

Figure: 8.1. Percentage of employment distribution in agriculture: gender wise for the year 2017-18

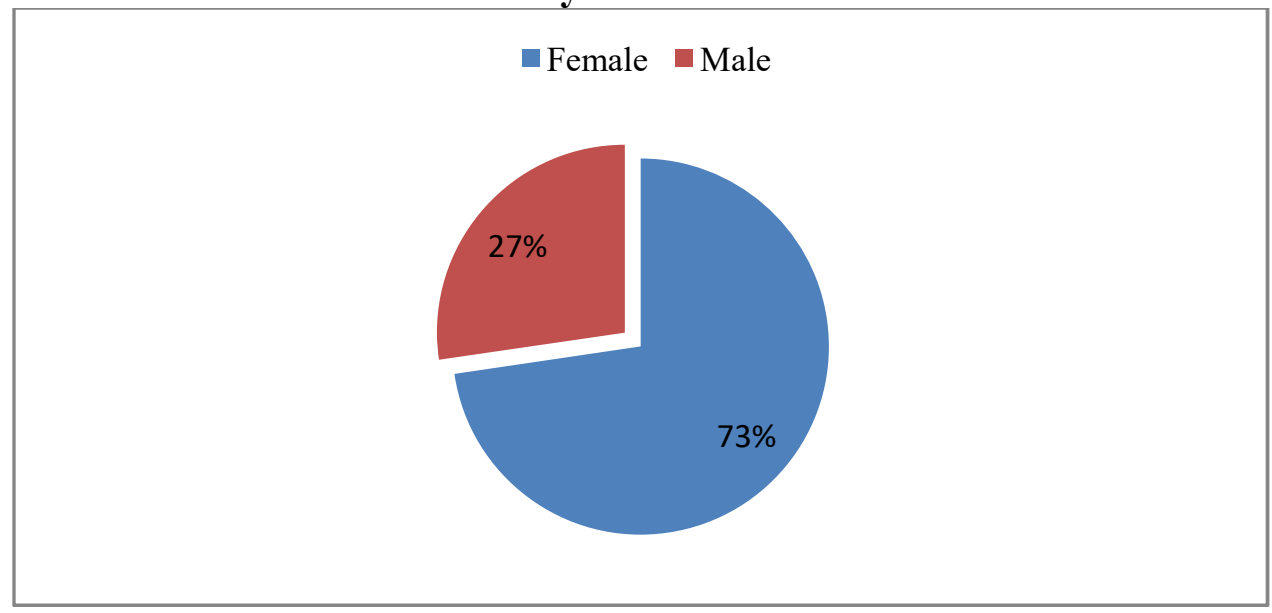

Data Source: Labor Force Survey of Pakistan 2017-18.

\section{Role in Fulfillment of Dietary Requirements of Pakistan}

Rural regions of Pakistan are famous for livestock keeping activities in country specially the regions of Sind and Punjab. In these regions major employing figure in farm related 
activities are found women but due to social backwardness their contribution is not realized rightly. In fact when we say the role of dairy industry in dietary requirements of country we are addressing the unregistered performance of rural women in dairy farming.

While addressing the dietary requirements of country we see, as the urban population raises the demand for dairy products is also got higher. According to a survey of Household Income and Expenditure (2017) consumption of milk in packaged or processed from is accounted for 36\%, consumption of milk in loose or fresh form delivered by milkmen is accounted for $64 \%$ and overall $88 \%$ of total population intends to consume this fresh or loose milk. Whereas dietary ingredients as kitchen consumption are $22 \%$ from milk and other dairy items. Different forms of milk are being consumed likewise Ultra Heat Treated (UHT), fresh, powdered, pasteurized, and condensed. Along all these some by products of milk are also been extensively used likewise butter fat, curd, cream, cheese, yogurt, ice-cream and confectionaries etc. Milk and its by products are extensively used in both the rural and urban regions of Pakistan. Due to the richness of protein and calcium, these products are almost a compulsory part of breakfast and dinner. The two major products of industry are milk (milk and milk equivalents) and eggs (laid by halal birds like hens and ducks etc.) are observed the important products both as raw (to be supplied for value addition) and final (after value addition) in industry. The demand of dairy products in country is fulfilled by 45 milk producing units. These units are operating as Joint Ventures (JVs) in the private ownership. The annual milk output is around 46 million tonnes of which only $6 \%$ is served in packaged form. During the last 5 years, in the sector $\$ 870$ million are being invested as both the foreign and local investment. This hike is a history record in the sector. The situation of dependency upon the import in sector could be clear from the fact that there is no infant milk producing unit in country.

In such a scenario the significance of technical assistance of rural women in industry is very crucial and need of time. Rural women lacks behind in sector while practicing commercial activities as their technical potential does not meet the demanded one of large scale value added units in industry.

\section{Role in Poverty Eradication}

Livestock does not only contribute larger in agricultural GDP but also have a prominent share in overall employment. As it is observed that in rural areas livestock are reared to meet the domestic dietary requirements and an excess of it are being sold commercially. Generally livestock are not kept for particularly commercial activities. In fact livestock provide the opportunity for marginal population to get involve in business activities (Economic Survey of Pakistan, 2016) and this incentive persuade them to raise the production than domestic needs. 
In rural areas it is also observed that livestock are kept by almost every family at domestic day to day dietary requirements. But the size of herd is 1 animal per family at an average actually the herd size depends upon the social status and income level. Here, women strata in rural regions are seemed to be more active in livestock related activities and found an opportunity to get involve in commercial activities through selling of excess production of milk and eggs than their domestic needs. Moreover, they also earn through value added products like butter fat, ghee, lassi and cheese etc. This helps to promote the sense among rural women of being involved in commercial activities and also enable them to support them in uplifting the income level of family. By having rural women in the fold of commercial activities on one end helps to eradicate poverty in country (Zaheer \& Hussain 2018) and on the other end promote the incentive industry of livestock. Likewise in Baluchistan these includes development of leather and wool industries. In the region there are 12 million sheep are recorded to obtain wool against an annual income of $\$ 5$ million (FAO, 2018). By creating an environment that promote gender unbiasness in commercial activities after farm will promote sense of economic responsibility among rural women that will lead to poverty eradication and uplifting the social status.

\section{Challenges Faced by Women in Dairy Industry of Pakistan}

Pakistan as third largest milk producing country does not meet the national demand, though production of milk could make country self-sufficient but still it is not independent in the sector and has to depend upon import. The following challenges are faced by both the gender in labour force but obviously has a deeper effect on women working there;

1. Challenge of lackness in quality supply chain

2. Challenge of seasonality

3. Challenge of energy crisis

4. Challenge of technology lackness in extension services

5. Challenge of herds' composition

6. Challenge of lackness in national guardianship

7. Challenge of ecological degradation

\section{Performance of Dairy Industry of Pakistan in International Trade}

In year 2017, the overall earnings from dairy export of Pakistan was around $\$ 30$ billion. The reason behind is the increasing familiarity of quality of milk exported by Pakistan in international market. Domestically the profit trend of industry remains constant despite of a reduction in sales by $7.8 \%$. It was due to the increasing price level in the country. Once again it will be rightly said that likewise the unregistered performance of rural women in 
productivity of dairy industry, there is also the hidden role of rural women in export earnings of country. Because the flow of dairy output is generated from the small farms and these farms have women in livestock keeping in the higher ratio of unpaid family worker. However the figure given below demonstrate the potential of dairy sector in international market. After the hike of 2014 the slower down trend is due to encountering ban on Pakistan's dairy products by its major trading partners due to lack of quality standards. Hopefully, after the removal of ban on dairy imports of Pakistan in the borders of Bahrain and UAE now once again a good export earnings could be enjoyed by sector.

Figure: 9.1. Export of dairy products of Pakistan.

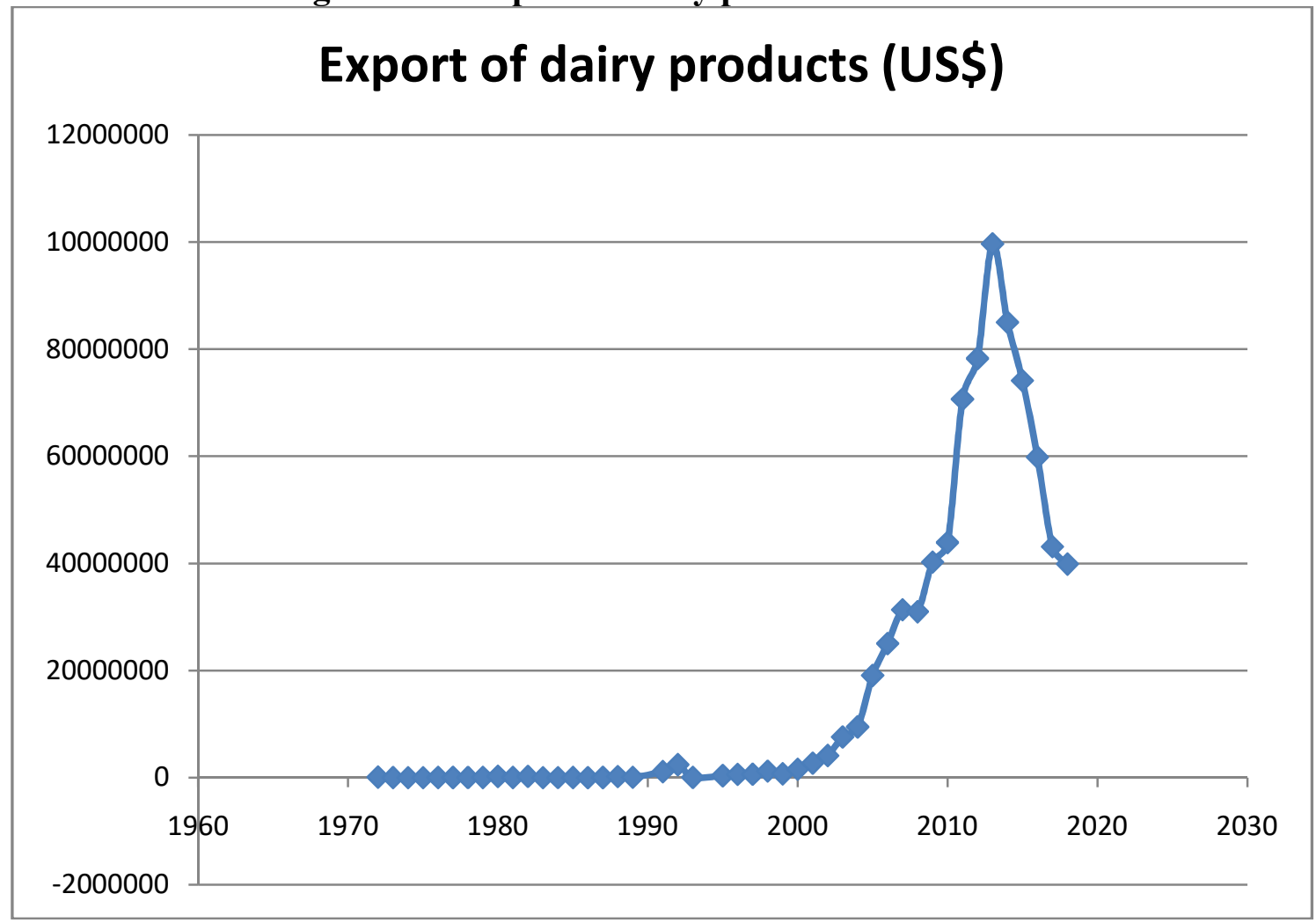

Source: Various reports of Bureau of Statistics of Pakistan.

\section{Descriptive Analysis and Discussion}

The selected data for descriptive analysis consists of 46 years of annual time series covering the period of 1961 to 2018. Table 9.1. shows the findings of descriptive statistics. This table represents that the mean of DPRODUCTS is 2.87324 and its standard deviation is 2.232979 , the mean of DEXPORT is $1.66 \mathrm{E}+08$ and its standard deviation is $8.65 \mathrm{E}+08$, the mean of DIMPORT is $3.13 \mathrm{E}+08$ and its standard deviation is $3.77 \mathrm{E}+08$, while the mean of WOMENEMPLOYEE is $5 \mathrm{E}+07$, and its standard deviation 
is $1 \mathrm{E}+07$. Jarque Bera Test is used to address the normality of variables, Table -9.1 . represents the probability values of corresponding variables DPRODUCTS, DEXPORT, and WOMENEMPLOYEE tells the normal distribution except DIMPORT. Skewness and Kurtosis are used to address the graphical shape and trend of variables used in data. Table 9.1. exhibits the negative skewness of DPRODUCTS, DEXPORT and WOMENEMPLOYEE and positive skewness of DIMPORT. The value of Kurtosis exhibits the leptokurtic or higher trend for variables of DPRODUCTS and DIMPORT and Platykutic or lower trend of DEXPORT and WOMENEMPLOYEE.

Table - 9.1

Descriptive analysis

\begin{tabular}{|l|c|c|c|c|}
\hline & DProducts & DExport & DImport & Women Employee \\
\hline Mean & 2.87324 & $1.66 \mathrm{E}+08$ & $3.13 \mathrm{E}+08$ & $5 \mathrm{E}+04$ \\
\hline Median & 2.652378 & $1.76 \mathrm{E}+09$ & $2.16 \mathrm{E}+08$ & $4 \mathrm{E}+04$ \\
\hline Maximum & 6.49321 & $3.21 \mathrm{E}+09$ & $1.73 \mathrm{E}+09$ & $5 \mathrm{E}+04$ \\
\hline Minimum & -2.177328 & $2.44 \mathrm{E}+08$ & 389932 & $2 \mathrm{E}+04$ \\
\hline Std. Dev. & 2.232979 & $8.65 \mathrm{E}+08$ & $3.77 \mathrm{E}+08$ & $1 \mathrm{E}+04$ \\
\hline Skewness & -0.275352 & -0.05648 & 3.237341 & -0.214 \\
\hline Kurtosis & 3.069184 & 1.77779 & 12.89062 & 2.004 \\
\hline Jarque-Bera & 0.186662 & 1.058343 & 98.07136 & 0.83 \\
\hline Probability & 0.903528 & 0.585041 & 0 & 0.66 \\
\hline
\end{tabular}

Source: Authors' desk

\section{Unit Root analysis}

After having a discussion on descriptive analysis, the Unit root test has also been performed to address the stationarity of data. In the Table 9.2. the results of Augmented Dicky Fuller at level and at 1st Difference are presented. Bt exhibiting the Table 9.1. DPRODUCTS and DIMPORT are found to be stationary at level while WOMENEMPLOYEE and DEXPORT are found stationary at 1 st difference.

Table -9.2

Unit root analysis

\begin{tabular}{|l|c|c|}
\hline Variables & Level & 1st Difference \\
\hline DProducts & 0 & \\
\hline DExport & 0.9995 & 0.0365 \\
\hline DImporT & 0.0003 & \\
\hline Women Employee & 0.9991 & 0.0000 \\
\hline
\end{tabular}

Source: Authors' desk 


\section{Conclusions}

Pakistan is ranked among the 4 largest milk producing and as well 4 largest livestock population country in world with special feature of its geographical position in the region. But it is observed that dairy sector of the country is not demonstrating its potential and needed role in food security in the country. There are many reasons behind this ineffective performance of sector. And among these the main topic of this study is the neglecting attitude of social and national ends towards almost $73 \%$ of employing labor force - the rural women. It is the need of time to cater rural women in terms of both the technical and financial assistance. Because their potentail involvement in the sector will help country to respond the dietary requirements. As, the dynamic condition of inhabitant style of population especially dietary patterns raises the demand of dairy products that influence the relative supply as well. Now this increasing demand either can be fulfilled by raising the production in sector or by importing the goods in cross border trade. In such a scenario if major employing strata involved in dairy farming is catered with right reforms then productivity of sector could be raised. Moreover, the productivity of sector is one aspect that reflects other aspects as well likewise uplifting living standards and food security can also be ensured by promoting rural women for commercialization of dairy farm activities. However the sector tries to demonstrate its potential but not as much successful as it is needed to meet domestic requirements and international competitiveness. Beside these all. the challenges faced by industry are also indicated in above discussion. The involvement of almost $60 \%$ of farmed livestock are managed non scientifically, resultantly negatively affect the productivity of industry. For this introduction of training programs to manage livestock at scientific approaches will help rural women to raise the productivity. Moreover, financial assistance also support them to get needed livestock feed and other necessary instruments that raise productivity as well as period of preservation. Pakistan's dairy industry has a sensitive relationship in economic prosperity. The export earnings from the sector could be enhanced if a serious attention will be given to facilitate the rural women so they could support not only their families but also helps to uplift the development of dairy sector.

\section{References}

Ahmad, S., Hinch, G., Prior, J., Thomas, P. \& Burrell, D. (2012). The Role of Extension in Changing the Dairy Industry in Pakistan: A Review. Journal of Animal and Plant Sciences, vol.22:2, pp.113-116.

Balagamwala, M., Gazdar, H. \& Mallah, H. B. (2015) (a). Synergy or Trade-Off between Agricultural Growth and Nutrition Women's Work and Care. The Pakistan Development Review, vol.54:4, pp.897-913. 
Balgamwala, M., Gazdar H. \& Bux H. Mallah (2015). (b). Women's Agricultural Work \& Nutrition in Pakistan: Findings from Qualitative Research", LANSA working paper series, Vol. 2015, No. 02. http://lansasouthasia.org/lansasouthasia/ /sites/default/files/Women_Agricultural_Work_\%20and_\%20Nutrition_\%20in_\% 20Pakistan1.pdf

Barro, R. J. (1996). Determinants of Economic Growth: A Cross-Country Empirical Study (No. w5698). National Bureau of Economic Research. https:/www.nber.org/ papers/w5698.pdf

Barro, R. Xavier. Sala-I-Martin (1995). Economic Growth. New York, McGraw Hill. Journal of Economic Dynamics and Control, Elsevier, vol. 21:5, pp.895-898.

Begum, R. \& Yasmeen, G. (2011). Contribution of Pakistani Women in Agriculture: Productivity and Constraints. Sarhad Journal of Agriculture, vol.27:4, pp.637-643.

Benhabib, J. \& Spiegel, M. M. (1994). The Role of Human Capital in Economic Development Evidence from Aggregate Cross-Country Data. Journal of Monetary Economics, vol.34:2, pp.143-173.

Butt, T. M., Hassan, Z.K., Mehmood K. \& Muhammad S. (2010), Role of Agricultural Development and their Constraints, Journal of Agriculture and Social Sciences, vol.9, pp.53-56.

Caballé, J. \& Santos, M. S. (1993). On Endogenous Growth with Physical and Human Capital. Journal of Political Economy, vol.101:6, pp.1042-1067.

Dries, L. \& Noev, N. (2006). A Comparative Analysis of Vertical Coordination in Dairy Chains in Poland, Slovakia and Bulgaria. Case Studies on Vertical Coordination in Agri-Food Chains in Eastern Europe and Central Asia. ECSSD Working Paper, vol.42, pp.135-166.

Dries, L. \& Swinnen, J. F. (2004). Foreign Direct Investment, Vertical Integration and Local Suppliers: Evidence from the Polish Dairy Sector. World Development, vol.32:9, pp.1525-1544.

Economic Survey of Pakistan, 2016, http://www.finance.gov.pk/survey/overview_201516.pdf

Economic Survey of Pakistan, 2017, http://www.finance.gov.pk/survey/overview_201617.pdf 
Economic Survey of Pakistan, 2018, http://www.finance.gov.pk/survey/overview_201718.pdf

Gasson, R. (1980). Roles of farm Women in England. Sociologia Ruralis, vol.20:3, pp.165-180.

Georgellis Y. \& Wall J. (2004). Gender Differences in Self-Employment, Federal Reserve Bank of St. Louis, Working paper. https:/files.stlouisfed.org/files/htdocs/ wp/1999/1999-008.pdf

Gillispie S., Harris J. \& Kadiyala S. (2012). The Agriculture Nutrition Disconnect in India: What do we know? IFPRI Discussion Paper. https://researchonline.lshtm.ac.uk/ 1440425/1/The_AgricultureNutrition_Disconnect_in_India_What_Do_We_Know .pdf

Hussain, S. \& Zaheer, R. (2016). Challenges to Dairy Sector and Role of Media: A Case Study of Pakistan (1975-2015), Journal of Mass Communication, vol.14:1, pp.85-108.

Jagadeesh, B. (2011). Women Entrepreneurship and Globalisation, http://52.172.159.94/ index.php/Vjmr/article/viewFile/84599/65216

Kathiriya, J. B., Damasia, D. M. \& Kabaria, B. B. (2013). Role of Rural Women in Dairy Farming of Rajkot District. Tamilnadu Journal of Veterinary and Animal Science, vol.9:4, pp.239-247.

Labor Force Survey of Pakistan 2017-18. http://www.pbs.gov.pk/content/labour-forcesurvey-2017-18-annual-report

Lal, R. \& Khurana, A. (2011). Gender Issue: The Role of Women in Agriculture Sector, International Journal of Business Economics and Management Research, vol.1:1, pp.29-39.

Lofstrom, M. (2013). Does Self-Employment Increase the Economic Well-Being of LowSkilled Workers? Small Business Economics, vol.40:4, pp.933-952.

Lucas, R. E. (1988). On the Mechanics of Economic Development. Journal of monetary Economics, vol.22:1, pp.3-42.

Mehta, S. \& Sethi, N. (1997). Targeting Women for Development, Social Welfare Journal, vol.43:10, pp.14-15. 
Mulligan, C. B. \& Sala-i-Martin, X. (1992). Transitional Dynamics in Two-Sector Models of Endogenous Growth (No. w3986). National Bureau of Economic Research. https://ideas.repec.org/p/nbr/nberwo/3986.html

Nelson, R. R. \& Phelps, E. S. (1966). Investment in Humans, Technological Diffusion, and Economic Growth. The American Economic Review, vol.56:2, pp.69-75.

Nwoye, M. (2007). Gender Responsive Entrepreneurial Economy of Nigeria: Ena-bling Women in a Disabling Environment. Journal of International Women's Studies, vol.9:1, pp.167-177.

Rathod, P. K., Nikam, T. R. \& Landge, S. (2016). Participation of Rural Women in Dairy Farming in Karnataka. Indian Research Journal of Extension Education, vol.11:2, pp. 31-36.

Rebelo, S. T. (1987). Long Run Policy Analysis and Long Run Growth (No. w3325). National Bureau of Economic Research, vol.99:3, pp.500-521.

Romer, P. M. (1986). Increasing Returns and Long-Run Growth. Journal of Political Economy, vol.94:5, pp.1002-1037.

Sarwar, M., Khan, M. A. \& Iqbal, Z. (2002). Status paper feed resources for livestock in Pakistan. International Journal of Agriculture \& Biology, vol.4:1, pp.186-192.

Women in Agriculture in Pakistan, Annual Report of Food and Agriculture Organiztion of the United Nations 2015. htrtp://www.fao.org/3/a-i4330e.pdf

Zaheer, R. \& Hussain, S. (a) (2015). Development of Dairy Sector and Trade Reforms in Pakistan, The International Journal of History and Social Sciences, vol.6:2, pp.58-79.

Zaheer, R. \& Hussain, S. (b) (2015). Globalization, Media Access and Role of Woman Entrepreneurship in Sustainable Economic Development of Pakistan, The International Journal of History and Social Sciences, vol.6:1, pp.57-81.

Zaheer, R., Hussain, S. \& Nadeemullah, M. (2018). Agricultural Development and the Role of Women's Self-Employment in Pakistan. Pakistan Journal of Gender Studies, vol.16, pp.103-120. 
Faridi, Z.M., Chaudhry, I.S. \& Malik, M.S. (2011). Why Women are Self-Employed? Empirical Evidence from Pakistan, International Journal of Economics and Finance, vol.3:1, pp.198-207.

Saman Hussain is Ph.D Scholar in the Department of Commerce, University of Karachi, Karachi, Pakistan.

Dr. Rummana Zaheer is an Associate Professor in the Department of Economics, University of Karachi, Karachi, Pakistan. 